\title{
Mamul Kuran $\quad$ RAZUMEVANJE UČENJA ODRASLIH IZ RANLJIVIH SKUPIN V OKVIRU KOGNITIVNIH TEORIJ UČENIA
}

\section{POVZETEK}

Kognitivne teorije učenja so se v sredini prejšnjega stoletja uveljavile kot kritika behaviorizma, kasneje pa so jih izpodrinile konstrukcionistične in konektivistične teorije učenja. V zadnjih dveh desetletjih so zaradi novih metodoloških možnosti psihološke raziskave kognicije doživele preporod. V prispevku so predstavljene izbrane raziskave s področij, ki se na različne načine dotikajo izobraževanja odraslih: postformalna faza kognitivnega razvoja, kognitivno staranje, pomen kristalizirane inteligentnosti v odraslem obdobju in raziskovanje učnih stilov. Prispevek zaključujejo raziskave s področja pismenosti ranljivih družbenih skupin in sklepno poglavje, v katerem so poudarjena uporabna dognanja za raziskovalce in izobraževalce v praksi.

Prispevek se vsebinsko napaja iz dveh ločenih virov. Prvi vir so Strokovne podlage za konceptualizacijo multimedijskih vsebin, ki so bile pripravljene na Andragoškem centru Slovenije v okviru projekta Razvoj pismenosti ter ugotavljanje in priznavanje neformalnega učenja od 2009 do 2011. Teoretični del strokovnih podlag je zajemal tudi kognitivne vidike učenja odraslih, ki so ogrodje pričujočega prispevka. Drugi vir je avtorjevo osebno udejstvovanje na področju kognitivne psihologije, bolje rečeno kognitivnih znanosti, kjer se še danes učenju in izobraževanju odraslih iz ranljivih skupin pripisuje marginalna raziskovalna vloga.

Ključne besede: kognicija, izobraževanje odraslih, postformalna faza kognitivnega razvoja, kristalizirana inteligentnost, učni stili

\section{APPLYING COGNITIVE LEARNING THEORIES TO UINDERSTANDING OF LEARNING IN VULNERABLE GROUPS ADULTS - ABSTRACT}

In the mid-twentieth century cognitive learning theories appeared as a criticism of behaviourism, and were later replaced by constructivist and connectivist learning theories. In the last two decades psychological research into cognition experienced a revival thanks to new methodological possibilities. This article brings a selection of research studies related to adult education in various ways: post-formal cognitive development stage, cognitive ageing, the meaning of crystallized intelligence in adulthood, and research into learning styles. The article proceeds with an account of research of literacy in vulnerable social groups and ends with a final chapter, which brings useful findings for researchers and adult education practitioners. In this article, the author has drawn from two separate sources. The first source are the professional premises underlying conceptualization of multi-media contents, prepared by the Slovenian Institute for Adult Education within the framework of the project titled Literacy development, and Assessment and Acknowledgement of Non-formal Learning between 2009 - 2011. The theoretical part of the underlying professional premises dealt, among other, with cognitive aspects of adult learning, which represent the basis of this article. The second source is the author's personal involvement in the field of cognitive psychology, or rather, in the field of cognitive sciences, in which even today learning and education of vulnerable groups of adults is given only marginal consideration in research.

Keywords: cognition, adult education, post-formal stage of cognitive development, crystallized intelligence, learning styles

UDK: $374.7: 159.95$

\section{UVOD}

Kognitivne teorije učenja imajo danes slab sloves. Ko se je v 50. letih prejšnjega stoletja kognitivni pristop uveljavil, je svojo utemeljitev iskal v kritiki behaviorizma, ki je prevladoval $\mathrm{v}$ pozni prvi polovici 20 . stoletja. Be- haviorizem je temeljil na predpostavki, da je človeško učenje specifičen odziv na dražljaj oziroma informacijo iz okolja. V tej mehanicistični perspektivi seveda ni bilo prostora za človeško duševnost, kjer se nove informacije 
spreminjajo v uporabno znanje. Celotno človeško vedenje je bilo dojeto kot nadzorovano, transparentno in vodljivo. Tako jasno stališče je bilo mogoče zato, ker je behaviorizem upošteval le vhodne (dražljaji iz okolja) in izhodne informacije (človeško vedenje), torej informacije, ki so dostopne neposrednemu opazovanju. Začetnik behavioristične paradigme Watson je obstoj duševnosti zato neposredno (duševnost ne obstaja) ali posredno (duševnost obstaja, a je ni mogoče znanstveno objektivno proučevati) zanikal (Malone, 1991: 113).

Kognitivne teorije učenja so bile posredna kritika behaviorističnega pristopa. Osredotočile so se na človeško duševnost kot prostor, kjer se učenje »dogaja«. Seveda so se zgodnji kognitivisti zavedali tudi dražljajev iz okolja in jih tudi upoštevali, vendar so ključno vlogo v procesu učenja pripisovali človeški duševnosti. Prve kritike behaviorizma so se pojavile na področju razumevanja jezika, ko je Chomsky opozoril, da radikalni behaviorizem ne more pojasniti kompleksnih slovničnih pravil, ki jih pozna človeštvo v vseh kulturah, da behaviorizem ne more pojasniti, kako ta pravila uravnavajo tvorbo povedi in je sploh možna komunikacija med ljudmi (Egan, 2009: 64). Za kognitiviste so bile behavioristične razlage na ravni prispodob in vsakdanjih predvidevanj brez resne preverbe (Anderson, 1995: 24), zato je njihovo poslanstvo »... iskanje pravil, načel, odnosov pri procesiranju novih informacij in iskanje smisla pri usklajevanju novih informacij s prejšnjim stanjem« (Bates in Poole v Bregar, Zagmajster in Radovan, 2010: 76 77). $\mathrm{V}$ tej želji so bile kognitivne teorije sicer uspešnejše kot behavioristični pristop, zaradi pretiranega poudarjanja individualnih, psiholoških in nevroloških dejavnikov, ki vplivajo na razumevanje in uporabo novih informacij v vsakdanjem življenju, pa so tudi same postale predmet kritik t. i. konstruktivističnih teorij učenja. Te pojmujejo učenje kot družbeni proces, ki zahteva komunikacijo ne le med udeleženci in učiteljem, temveč tudi med udeleženci, kolegi, prijatelji in širšo socialno skupnostjo. V paradigmi konstruktivističnega učenja »prostor « učenja ni duševnost posameznika, ampak družbeni kontekst, v katerem posamezniki negujejo interakcije med sabo in institucijami. Tudi znanje, ki je označeno kot »veljavno«, je (le) proizvod družbene konstrukcije in je kot tako lahko podvrženo dvomu in preverjanju.

Danes v ospredje stopa konektivistična teorija učenja, ki temelji na domnevi, da je znanje porazdeljeno po človeških, družbenih in tehnoloških omrežjih, učenje pa je dejansko proces povezovanja, širjenja in upravljanja teh omrežij. Ta omrežja lahko imajo različne modalitete, od živčevja (nevronske mreže) do povezovanja s pomočjo spletnih tehnologij. Posebno pomembno vlogo $\mathrm{v}$ konektivizmu ima učitelj, ki vodi, usmerja in izboljšuje ka-

Danes v ospredje
stopa konektivistic-
na teorija učenja.
kovost omrežij, ki jih oblikujejo učeči se (Siemens in Tittenberg v Bregar, Zagmajster in Radovan, 2010: 78). Ideja ni nova, zagovarjal jo je že Vigotski (Egan, 2009: 80), se je pa znotraj konektivistične paradigme na novo inkarnirala $\mathrm{v}$ sodobnejši obliki.

Na prvi pogled se zdi, da navedene teorije druga drugi konkurirajo. A v resnici se lahko strinjamo z Illerisom (2007: 23), ki pravi, da gre pri različnih teorijah učenja za komplementarne razlage procesov znotraj skupnega pojmovnega okvirja. Po njegovem učenje odraslega človeka vsebuje dve razsežnosti. Prvi proces se dogaja $\mathrm{v}$ medosebnem prostoru, kjer so pomembni kulturno ozadje in družbeni pogoji delovanja. Veliko tovrstnega učenja, ki smo mu priče danes, pred nekaj sto ali nekaj tisoč leti ni bilo mogoče. Sodobno učenje je izrazito odvisno od tehnoloških in kulturnih pogojev, $\mathrm{v}$ katerih se posameznik uči. Drugi proces se dogaja v posamezniku. Dejavniki, ki vplivajo na učenje na ravni posameznika, so plod dolgotrajnih evolucijskih prilagoditev, sami pa smo danes dediči izredno prilagojenega in fleksi- 
bilnega kognitivnega sistema, ki nam omogoča spoznavanje novih informacij, primerjanje teh informacij s preteklimi izkušnjami in učinkovito uporabo pridobljenega znanja v vsakdanjem življenju. To raven učenja učinkoviteje pojasnjujejo kognitivne teorije učenje, popolnoma neuporaben pa na tej ravni ni niti zmerni behaviorizem. Različne ravni procesa učenja gnezdijo druga v drugi, izhajajo iz bioloških in psihološko-evolucijskih osnov ter se nadgrajujejo z novimi, družbeno vzpostavljenimi dejavniki, ki spodbujajo ali onemogočajo učinkovito učenje v sodobnem svetu. Katerakoli teorija učenja, ki ne upošteva obeh navedenih vidikov, je $\mathrm{v}$ temelju redukcionistična, nekonsistentna in v končni fazi tudi neuporabna: »Učenje razumemo kot zapleten in kompleksen predmet proučevanja. Ta mora izhajati iz psiholoških dognanj, ki temeljijo na raziskavah in dolgoletnih izkušnja, bioloških temeljih, predvsem razumevanju delovanja možganov, hkrati pa moramo upoštevati socialni kontekst in sodobno strukturo delovanja, tako v vsakdanji praksi kot v splošni organiziranosti izobraževalnih priložnosti.«(Illeris, 2007: 21.)

V zadnjih dveh desetletjih so kognitivne teorije učenja doživele preporod. Zakaj? K temu so delno pripomogle nove tehnologije, kot so funkcionalna magnetna resonanca (fMRI), elektroencefalogram (EEG) in tehnologija SPECT, ki razširjajo metodološke možnosti proučevanja in razumevanje spoznavnih procesov med učenjem odraslih oseb. Poleg tega so kognitivne teorije učenja začele resno upoštevati kritike konstruktivističnega pristopa $\mathrm{k}$ učenju in $\mathrm{v}$ svoje pojasnjevalne modele učenja umeščati tudi socialne, kulturne in celo politične dejavnike, ki spodbujajo ali onemogočajo učinkovito učenje (Blachard-Field in Kalinauskas, 2009).

V nadaljevanju se osredotočamo na te sodobne raziskave in poskušamo $\mathrm{v}$ ospredje postaviti uporabna spoznanja za izobraževalce. Načelno razpravo med psihološkim in družboslovnim pristopom $\mathrm{k}$ proučevanju učenja odraslih pri tem puščamo ob strani. V osrednjem delu so predstavljeni nekateri temeljni koncepti in raziskave, prispevek pa zaključuje nekaj kratkih uporabnih izhodišč, ki jih je smiselno upoštevati $\mathrm{v}$ raziskovalni in izobraževalni praksi.

\section{NEOPIAGETOVSKI POGLED NA RAZVOJ KOGNICIJE ODRASLE OSEBE}

Eno najbolj uveljavljenih tipologij kognitivnega razvoja je ponudil Piaget. Po njegovih raziskavah poteka kognitivni razvoj posameznika v štirih kvalitativno ločenih fazah. Kvalitativno stanje kognicije strogo določa posameznikovo razumevanje in interpretacijo realnosti, kar je seveda neposredno povezano z njegovimi strategijami učenja. Tisto, kar se od stopnje do stopnje spreminja, so t. i. kognitivne sheme, razmeroma stabilno strukturirane odslikave realnega sveta, ki v mentalnem sistemu otroka in mladostnika pomenijo nujno stalnico oziroma sidrišča v nenehno spreminjajočih se razmerah v okolju, v katerem deluje.

Prva, senzo-motorična stopnja traja od rojstva do drugega leta. $V$ tej fazi je prioritetna naloga kognicije otroka predvsem usklajevanje zaznav in gibov $\mathrm{v}$ občutek za razvoj konstantnosti objektov ter specializacija nevronske mase za različne kognitivne procese, ki se manifestirajo v kompleksnejših fazah razvoja mišljenja. Druga faza traja do sedmega leta starosti. V ospredje stopijo občutek o lastni eksistenci, egocentristično dojemanje sveta, močna domišljija, zasnove logično operativnega mišljenja, generalizacija pravil ter preverba teoretskih načel v praksi. Na tretji stopnji (sedem do enajst let), stopnji konkretno logičnega mišljenja, je kognitivni preskok največji. Mišljenje otroka dobi obrise mišljenja odrasle osebe, omogočena je konzervacija novih informacij, izvajajo se miselni eksperimenti, vzporedne multiple klasifikacije, očitna pa postane tudi reverzibilnost mišljenja. Po Piagetu v tej fazi še vedno obstajajo nekatere težave pri abstraktnem mi- 
šljenju, ki so v središču na četrti, zadnji stopnji razvoja mišljenja. Ta nastopi po 12. letu starosti. V tej formalno logični fazi mišljenje postane abstraktno, razmišljanje kot temeljna epistemološka strategija spoznavanja sveta se avtomatizira, za pridobivanje znanja pa se uveljavi hipotetično-deduktivno mišljenje. Oseba $\mathrm{v}$ tej fazi ne uporablja več strategije poskusov in napak, ampak sistematično generira možne hipoteze in manipulira eno spremenljivko, pri čemer preostale dejavnike $\mathrm{v}$ miselnem eksperimentu ohranja pod enakimi pogoji.

Na trajanje posameznega stadija vplivajo spodbude iz socialne okolice. Ti stadiji so kumulativni, kar pomeni, da se vzorci, pridobljeni v prejšnji fazi mišljenja, ohranijo in nadgradijo, ne pa »prepišejo« in zamenjajo z novim kognitivnim stanjem. Stopnje stadija so tudi fiksne in nezamenljive, pogojene $\mathrm{z}$ evolucijsko-psihološkimi prilagoditvami v razvoju človeštva. $\mathrm{Ne}$ glede na to, da so nekateri sklepi faznega modela, ki ga je razvil Piaget, očitno koketirali $\mathrm{z}$ behaviorizmom in vedenjsko teorijo učenja, ki naj bi potekalo v socialnem vakuumu, se je model obdržal, saj v splošnem nazorno strukturira evolucijo človeške kognicije na ravni posameznika (Myers, 2007: 147-154).

Resnejši očitek je v zadnjih dveh desetletjih prišel od raziskovalcev kognitivnih procesov odraslih. Po mnenju Piageta se kognitivni razvoj v mladostniškem obdobju malodane konča. Nove kvalitete, ki se pojavijo v obdobju odraslosti, so po njegovem tako minimalne, da o kakšnem nadaljevanju štirifazne sheme kognitivnega razvoja ni treba razmišljati. Izkušnje iz izobraževanja in učenja odraslih tej predpostavki čedalje bolj nasprotujejo (Sinnott, 2009: 108). Zdi se, da duševnost odrasle osebe razpolaga z nekaterimi lastnostmi, ki jih je Piaget prezrl; bodisi zaradi preteklega raziskovalno-akademskega nezanimanja za kognicijo odraslih oseb bodisi zaradi odsotnosti pogojev, ki bi takšno raziskovanje sploh omogočali.

Riegel (Bakračevič Vukman, 2000: 19) in Sinnott (2009) zato vpeljujeta novo fazo ko- gnitivnega razvoja človeka, ki je še kompleksnejša od formalno logične faze, in jo imenujeta »postformalna « faza kognitivnega razvoja, značilna za odraslo osebo. Ta je po njunem sintetična in poleg klasičnih kognitivnih procesov (funkcije nove možganske skorje, kot so spomin, zaznava, govor, načrtovanje, sklepanje itd.) vključuje tudi konativne psihološke procese (motivacija, čustva in občutki). Sinnott (2009: 106) tukaj kot pogoj za razvoj postformalne faze omenja nujnost intenzivnih interakcij z drugimi odraslimi, ki imajo drugačne poglede na svet kot mi sami. Posodobitev sheme kognitivnega razvoja po Piagetu je pomembna inovacija, saj mišljenje, učenje in izobraževanje odrasle osebe postavlja kot avtonomno polje raziskovanja. Aleksander in Langerjeva (Bakračevič Vukman, 2000: 19) te neopiagetovske modele razdelita na nehierarhične in hierarhične. Prvi postavljajo pod vprašaj obstoj globalnih hierarhičnih stadijev $\mathrm{v}$ odraslosti in odraslo dojemanje sveta vidijo kot samosvojo fazo, ločeno od štirih omenjenih faz, ki predstojijo postformalni stopnji mišljenja. Drugi, hierarhični, predpostavljajo, da je postformalna faza kognitivnega mišljenja pravzaprav logično nadaljevanje, neke vrste peta faza razvoja mišljenja pri človeku. Raziskovalci s tega področja so posebno pozorni na posebnosti v kognitivnem dojemanju sveta, ki se razlikujejo od faz mišljenja v otroštvu in adolescenci. Te specifične lastnosti seveda vplivajo tudi na način, kako se odrasli učijo, kako zaznavajo svet okrog sebe in kako dojemajo učenje v odrasli dobi svojega življenja. To v sebi skriva velik potencial za različne prilagoditve učnih strategij pri poučevanju odraslih in s tem za izboljšanje učinkovitosti izobraževalnih programov. Ne glede na delitev, ki sta jo predlagala Aleksander in Langerjeva, se vsi strinjajo, da se v odraslem obdobju pojavi neka specifična noviteta $v$ interpretaciji sveta, ki je prejšnje faze ne poznajo.

Razlage o tem, zakaj se pojavljajo razlike v učenju odraslih in otrok oziroma mladostnikov, so 
prav tako različne. Dittman-Kohlijeva in Baltes (Bakračevič Vukman, 2000: 20) denimo govorita o dveh različnih sistemih inteligence na ravni posameznika: mehanični in pragmatični inteligentnosti. K prvi sodijo osnovne, kontekstualno neobremenjene kognitivne zmožnosti (to so prav operacijske faze, kot jih je opredelil Piaget v svojem izvornem modelu kognitivnega razvoja). Razvoj te inteligentnosti se po njunem mnenju lahko opiše v stadijih. Razvoj pragmatične inteligentnosti pa ima drugačno strukturo. Mehanična inteligentnost je po prepričanju Dittman-Kohlijeve in Baltesa nujen, ne pa zadosten pogoj pragmatične inteligenUčenje odraslih je kompleksen proces. tnosti; ta za svojo uveljavitev potrebuje še življenjske izkušnje in bogato socialno interakcijo, kar je poudaril Sinnott (2009). Pragmatična inteligentnost je torej »diferentia specifica«, po kateri se kognicija odraslega posameznika razlikuje od otroške kognicije in kognicije adolescenta. Razvija se predvsem takrat, ko je treba obstoječe veščine uporabiti v praktičnem kontekstu in vpostaviti individualiziran sistem učinkovitosti in znanja.

Najžlahtnejša sinteza obeh vrst inteligentnosti lahko po Dittman-Kohlijevi in Baltesu (Brakračevič Vukman, 2000: 20) preide $\mathrm{v}$ to, kar poznamo pod pojmom modrost. Ta integrira kognitivne, afektivne in reflektivne komponente človeškega duševnega življenja (Ardelt in Jacobs, 2010: 732).

\section{KOGNITIVNO STARANJE IN IMPLIKACIJE ZA IZOBRAŽEVANJE ODRASLIH}

Empirično raziskovanje spoznavnih procesov odraslih v razmerju do učenja je šele v povojih, kar pomeni, da je večina dognanj še vedno na ravni teorije. Blackmore in Frith (Mast, Zimmerman in Rowe, 2009: 695) navajata tri ključne razloge, zakaj je tako.
Prvi razlog je ta, da je raziskovanje učenja in izobraževanja za sabo pustilo številne discipline in koncepte, ki so ostali nepovezani in neusklajeni. Če je že prihajalo do interdisciplinarnega povezovanja, se je to dogajalo na področju razvojne psihologije, kjer je bil raziskovalni fokus usmerjen v obdobje otroštva in mladostništva. Drug pomemben dejavnik je ta, da je notranja variabilnost odraslih neprimerno bolj kompleksna kot pa notranja variabilnost mladostnikov in otrok. Odrasli imajo bistveno več življenjskih izkušenj in prirojeni potenciali (tudi za učenje) se pod vplivom unikatnih izkušenj v različnih kulturnih kontekstih zelo različno manifestirajo. Povečana verjetnost za različne nevrološke motnje, kot je Parkinsonova ali Alzheimerjeva bolezen v odraslem obdobju, to heterogenost samo še poudari. Tretji dejavnik slabo raziskanega kognitivnega staranja je znana šibka točka kognitivne znanosti nasploh. To je splošno znano dejstvo, da je učenje odraslih izredno kompleksen proces, v katerega so vključeni različni možganski predeli in kognitivni mehanizmi. Tako imenovano kognitivno staranje se ne dogaja enakomerno po novi možganski skorji, ampak se različni predeli možganov različno hitro »starajo«, kar se kaže tudi v različnem pešanju kognitivnih procesov.

Seattle Longitudinal Study (SLS) iz leta 2005, v kateri so raziskovali prav učenje odraslih, je vendarle ovrgla mit o tem, da so vse kognitivne sposobnosti, ki so vpete $\mathrm{v}$ proces učenja, obratno sorazmerne z dejavnikom staranja (Mast, Zimmerman, Rowe, 2009: 696). Izkazalo se je, da nekatere intelektualne sposobnosti odraslih ostajajo na isti ravni kot pri mladostnikih, druge upadajo, nekatere pa se celo izboljšujejo vse do 60. leta starosti. Študija SLS je pokazala, da se besedni spomin (slušno sprejemanje informacij) med 50. in 60. letom $\mathrm{v}$ povprečju celo nekoliko izboljša. Sposobnost besednega izražanja ostane $\mathrm{v}$ povprečju razmeroma stabilno vse do 80. leta, numerične sposobnosti sicer oslabijo nekoliko prej, občutno upadanje pa se v povprečju zgodi šele od začetka 70 let naprej. 
Haser in Zack (Mast, Zimmerman, Rowe, 2009: 697) sta ob tem podala splošno ugotovitev, skupni imenovalec, ki zadeva vse odrasle. Po njunem je treba upoštevati, da $\mathrm{v}$ odraslem obdobju upade sposobnost selekcije nepomembnih dražljajev, zaradi česar odrasli pogostokrat manj pomembne informacije za dosego nekega cilja upoštevajo z enakim zanosom kot bolj pomembne informacije. Tako nastaja »mentalna navlaka«, presežek nepomembnih informacij v delovnem spominu, ki onemogoča, da bi se pridobljene informacije učinkovito kodirale v dolgoročni spomin. Zaradi tega se pogosteje pojavljajo napake pri prepoznavanju osvojenega znanja. Če bi torej lahko v ospredje postavili samo eno bistveno razliko med pridobivanjem novega znanja pri mladostniku in pridobivanjem novega znanja pri odrasli osebi, bi to po mnenju Haserja in Zacka bila bistveno učinkovitejša selekcija relevantnih informacij pri mlajši populaciji oziroma težave pri opuščanju manj pomembnih dražljajev iz okolice pri starejši populaciji.

Fischer je kognitivno staranje ali bolje rečeno kognitivno odraščanje iskal na nevrofiziološki ravni. Po njegovem vsaka stopnja kognitivnega razvoja, o kateri je govoril Piaget, korelira z nastankom novega tipa nevronske mreže. V adolescenci in odrasli dobi razširitve nevronskih mrež niso več tako drastične kot v zgodnjem otroštvu. $\mathrm{V}$ otroštvu je namreč dosežena dvakrat tolikšna sinaptična gostota kot $\mathrm{v}$ novi možganski skorji odraslega. Ta postopno upada skozi vsa življenjska obdobja, ki se končajo v pozni odrasli dobi. Sinaptična gostota $\mathrm{v}$ možganskem predelu za vizualno zaznavo $v$ tem obdobju še vedno presega sinaptično gostoto možganskih predelov za sprejemanje dražljajev po drugih zaznavnih kanalih, kar pomeni, da vizualna zaznava ostaja hegemonski čut tudi v odrasli dobi (Bakračevič Vukman, 2000: 38-39).

Tako kot ni enoznačne oblike kognitivnega staranja - kot smo videli iz longitudinalne raziskave SLS, nekatere intelektualne sposobnosti upadajo hitreje, druge počasneje - tako tudi ni
»... enoznačnega vzorca sprememb možganskega tkiva« (Schaie v Mast, Zimmerman in Rowe, 2009: 698). Atrofija (krčenje) možganskega tkiva je sicer tipičen proces staranja, a Raz je primerjal hitrosti staranja različnih predelov nove možganske skorje in ugotovil, da se v odrasli dobi najbolj skrči čelni reženj nove možganske skorje, ki je odgovoren za »začasno organizacijo in koordinacijo kompleksnih vedenjskih sekvenc, ki jih posameznik dojema kot inovacijo « (West v Mast, Zimmerman in Rowe, 2009: 700). Druga pomembna funkcija čelnega režnja nove možganske skorje je nadzorovanje začasnega spomina, ki ohranja informacije $\mathrm{v} »$ stand-by « stanju za nadaljnjo uporabo $\mathrm{v}$ delovnem spominu. $\mathrm{Z}$ drugimi besedami, čelni reženj nove možganske skorje je ključen za pridobivanje novega znanja oziroma učenje. Raz je do tega spoznanja prišel s pomočjo obširne medsekcijske študije, v kateri je opazoval korelacijo kronološke starosti udeležencev in prostornine različnih predelov nove možganske skorje. $\mathrm{V}$ primerjavi s senčnim delom nove možganske skorje (procesiranje vizualnih zaznav), temenskim režnjem (integracija vseh dražljajev in prostorska orientacija) in zatilnim režnjem (registracija slušnih zaznav in razumevanje govora) največ prostornine $\mathrm{v}$ obdobju odraslosti izgubi prav čelni reženj. Kljub temu to ne pomeni, da se kognitivno pospešeno stara samo nova možganska skorja. Raz (Mast, Zimmerman in Rowe, 2009: 698) omenja še hipokampus, del starejšega, limbičnega sistema možganov, ki je odgovoren za interakcijo med delovnim in dolgoročnim spominom.

Kot ustrezen okvir, znotraj katerega je mogoče razumeti omenjene spremembe, Mast, Zimmerman in Rowe (2009: 725) predlagajo koncept selektivne optimizacije s kompenzacijo (ang. Selective Optimisation with Compensation). Gre za to, da spremembe, povezane s kognitivnim staranjem, »... silijo odrasle učeče se, da izbirajo manj učnih projektov, da optimizirajo razpoložljive zmožnosti in znanje ter 
uporabljajo kompenzacijske tehnike učenja za dosego enakega učnega učinka«. Pri tem interaktivnem procesu ima pomembno vlogo tudi podporno okolje.

Priporočljivo je, da si odrasli oblikujejo prioritetni seznam področij, ki jih zanima, izberejo tista področja, kjer želijo dejansko pridobiti novo znanje, in reducirajo množico številnih področij, na katerih so bili dejavni v preteklosti. Pridobivanje znanj na več področjih postaja namreč v odraslem obdobju težje. To seveda še zdaleč ne pomeni, da v odraslem obdobju življenja ni mogoče najti novih znanj, konjičkov ali talentov, jih negovati, nadgraditi in mogoče spremeniti v prevladujočo življenjsko dejavnost, so pa takšni odrasli v manjšini. Optimizacija je logični naslednji korak, ki sledi selekciji. Z optimizacijo je mišljena preusmeritev fokusa učenja $\mathrm{z}$ neštetih razpršenih področij na nekaj izbranih področij, za katere posamezniki ocenjujejo, da so v njihovem življenju najpomembnejša. Posledica tega je, da je učenje bolj učinkovito. Kompenzacija je zadnji, skrajni izhod. Po mnenju Marksiska in drugih (v Mast, Zimmerman in Rowe, 2009: 716) pride do kompenzacije takrat, »...kadar se kognitivni potenciali znižajo pod potrebno raven za ustrezno učenje v odraslem obdobju«. Uveljavijo se alternativne učne strategije, drugačni pristopi, s katerimi se posameznik poskuša izogniti težavam, ki se pojavljajo zaradi kognitivnega staranja.

Seveda to ni edini način, kako se selekcija področij, optimizacija učenja in kompenzacija učnih pristopov izrazijo v praksi. Neredko se zgodi, da odrasli kot kompenzacijo uporabijo skupinsko učenje znotraj organiziranega tečaja. Marsikateremu odraslemu, ki je vpet v učne procese, predavanje $\mathrm{v}$ skupini olajša načrtovanje in organizacijo učenja, hkrati pa lahko predavatelja in soudeležence programa povpraša o ustreznosti posameznih korakov pri učenju in vajah iz, denimo, računalništva ter tako pridobi neposredne odzive, ki jih jemlje kot vodila za naprej. V tem primeru je večja naklonjenost skupinskemu kot samostojnemu učenju pod mentorstvom študenta prostovoljca lahko kompenzacijska strategija. Slabšo osebno motivacijo in organizacijske sposobnosti, ki jih pri individualnem učenju v javni knjižnici vsekakor potrebujemo, lahko posameznik nadoknadi s pomočjo kontinuirane podpore učeče skupine. V okviru opisanem primeru starejše gospe bi slednje $\mathrm{z}$ izbiro skupinskega učenja pred individualnim učenjem lahko pridobila pri osebni motivaciji, ki bi jo črpala iz predanosti skupini. Možnost zastavljanja dodatnih vprašanj učitelju in drugim udeležencem bi ji lahko olajšalo sledenje vsebini, kar bi posledično vplivalo na večjo učinkovitost učenja. Vendarle pa je treba omeniti, da je večja naklonjenost skupinskemu učenju sicer lahko kompenzacijska strategija, tako kot je opisana na tem mestu, a je izbor skupinskega učenja namesto individualnega po mnenju Willisa (v Mast, Zimmerman in Rowe, 2009: 718) večkrat $v$ vlogi selekcije in optimizacije.

Poskušajmo si zdaj predstavljati, kako ti trije procesi delujejo v praksi. Vzemimo za primer odraslo gospo, ki jo že nekaj časa zanima uporaba računalnika v vsakdanjem življenju. Z njim v preteklosti ni imela veliko stika, se pa zaveda, da ji lahko olajša vsakdanje življenje. Da se bo lahko bolj resno posvetila učenju računalništva oziroma digitalnemu opismenjevanju, bo opustila nekaj drugih dejavnosti, ki ji osebno ne pomenijo toliko (selekcija). Prepričana je, da bo s pomočjo osvojenega znanja več komunicirala s svojimi sorodniki, predvsem vnuki, kar ji bo prineslo dodatno čustveno zadoščenje, ki ga trenutno pogreša (optimizacija). Gospa tudi ocenjuje, da ji manko predznanja s področja novih tehnologij onemogoča, da bi dosledno sledila organiziranim skupinskim tečajem računalništva. Predavanja so zanjo preveč strukturirana, tej strukturi pa le s težavo sledi. Zato se je odločila, da bo svojo pot digitalnega opismenjevanja začela v splošni knjižnici, pod individualnim mentorstvom študenta prostovoljca. Tako bo zaobšla nelagodje, ki ga čuti v družbi tujih odraslih, ki jim je sodoben, hiter slog življenja bliže, hkrati pa se učinkovito digitalno opismeni. 
Če sklenemo: kognitivno staranje pomeni upadanje nekaterih potencialov za učenje, ki so bili v otroškem in mladostniškem obdobju vitalnejši. Raziskave kažejo, da se najhitreje stara čelni reženj nove možganske skorje, kjer je sedež najpomembnejših višjih kognitivnih procesov za učenje odraslih oseb. Te biološke spremembe lahko pripeljejo do osebnostnih sprememb v strategijah učenja. Zelo uporaben za pojasnitev interakcije med kognitivnim staranjem in osebnim spoprijemanjem s težavami, ki izhajajo iz kognitivnega staranja, je model selektivne optimizacije s kompenzacijo. Ključno spoznanje za raziskovalce in izobraževalce odraslih je, da odrasla doba ne prinaša samo upada kognitivnih sposobnosti na psihološki ravni, ampak tudi vznik novih učnih strategij in pristopov $\mathrm{k}$ učenju, s katerimi odrasli izbirajo, optimizirajo in nato kompenzirajo upad kognitivnih sposobnosti. Pri teh novih učnih strategijah postane socialno okolje, v katerem se učenje dogaja, še pomembnejši dejavnik kot $\mathrm{v}$ otroškem in mladostniškem obdobju. Tough (v Mast, Zimmerman in Rowe, 2009: 718) navaja, da socialni vidik učenja (druženje z vrstniki) pri starejših optimizira dve ključni področji njihovega življenja: uporabo novega znanja v vsakdanjem življenju in kakovost življenja nasploh z bogatimi interakcijami. Prav zato se večina odraslih, kljub nekaterim očitnim prednostim samostojnega učenja, odloča za skupinsko obliko učenja. Mast, Zimmerman in Rowe (2009: 718) to ugotovitev jedrnato povzamejo, ko pravijo, da učenje v skupinski situaciji odraslim učečim se omogoča reševati naloge, ki jih je v preteklih obdobjih njihovega življenja brez težav reševal takrat bistveno vitalnejši čelni reženj nove možganske skorje.

\section{KRISTALIZIRANA \\ INTELIGENTNOST - ZNAČILNOST ODRASLE DOBE}

Osredotočimo se zdaj na različne dimenzije inteligentnosti v odrasli dobi. Že omenjena deli- tev na mehansko in pragmatično inteligentnost (Dittman-Kohlijeva in Baltes $\mathrm{v}$ Bakračevič Vukman, 2000: 20) delno sovpada z delitvijo na deklarativno in proceduralno znanje (Reif, 2008: 32) in Cattellovo delitvijo inteligentnosti na dva prevladujoča dejavnika: fluidno in kristalizirano inteligenco. Pri prvi gre za tako imenovano biološko pogojeno komponento inteligentnosti: logično reševanje problemov, novih situacij, prepoznavanje vnaprej naučenih vzorcev in algoritmov reševanja itd. Pri kristalizirani inteligentnosti pa gre za veščine, znanje in predvsem izkušnje, ki so si jih posamezniki pridobili v različnih kontekstih, ter razširjeno, bogato besedišče, s katerim natančneje opišemo stanja, v katerih se nahajamo (Myers, 2007: 184 in Sternberg, 1999: 460).

Crook in West sta to delitev osvetlila $\mathrm{z}$ raziskavo, v kateri sta $\mathrm{k}$ sodelovanju povabila 1.205 oseb, da bi proučila, kako se odrasli učijo. Udeležencem raziskave sta prikazala posnetke 14 oseb, ki so se predstavile s svojim imenom in domačim krajem. Vključen je bil torej vizualni in slušni dražljaj. Sodelujoči so morali obnoviti čim več imen oseb s posnetkov po prvem, drugem in tretjem gledanju. Pričakovano so vsi, ne glede na starost, bolje obnovili imena po večkratnem gledanju, a so mladostniki in mlajši odrasli stalno presegali odrasle $\mathrm{v}$ obnavljanju imen, kar nakazuje na učinkovitejše delovanje delovnega spomina. Podoben upad spominskih sposobnosti so zaznale tudi druge raziskave, zato ni presenetljiva samoocena dveh tretjin starejših od 40 let, da je njihov delovni spomin nedvomno šibkejši, kot je bil takrat, ko so bili mlajši (v Myers, 2007: 182).

Shonfield in Robertsonova sta izvedla podobno raziskavo, s tem da so udeleženci prepoznavali imena na dva različna načina. $V$ prvi mešani skupini mladostnikov in starejših odraslih so udeleženci obnavljali imena, ki so jih pred tem prebrali. V drugi skupini so imena prepoznavali na pisno pripravljenem seznamu. Na tem seznamu so bila navedena imena z začetnega seznama in dodana nova imena, ki niso bila na prvem sezna- 
mu. Raziskovalca sta ugotovila, da so se v prvi skupini bolje odrezali mlajši, iz česar sta izpeljala podoben sklep kot Crook in West, da torej sposobnost obnovitve osvojenih novih informacij z leti upada. Pri prepoznavanju imen z zapisanega seznama pa se sposobnosti starejših odraslih niso niti malo razlikovale od sposobnosti mladostnikov. Rezultati odraslih so bili zelo podobni rezultatom mladostnikov. Ker je edini spremenjeni pogoj oblika, v kateri je nova informacija podana, so raziskovalci sklepali, da je učinkovitost učenja v odrasli dobi precej odvisna tudi od tega, kako so nove informacije podane. Možnosti preverjanja osvojenega znanja je seveda več: ustno, pisno, s prepoznavanjem (izbirni odgovori), z odprtimi odgovori in podobno. Ključno sporočilo opravljene študije je, da bo rezultat pri vsakem od omenjenih oblik preverjanja osvojenega znanja nekoliko drugačen, tudi če bo na omenjene oblike preverjanja odgovarjala ista odrasla oseba. Razlike v rezultatih lahko $\mathrm{z}$ veliko gotovostjo pripišemo različnim oblikam preverjanja znanja. Kako si torej odrasli zapomnijo novo znanje ter shranjujejo in uporabijo nove naučene vsebine, je odvisno od oblike, v kateri so nove informacije posredovane. Tudi to je ena izmed ključnih ugotovitev za izobraževalce odraslih.

Burke in Shafro (Myers, 2007: 182) k temu dodajata, da je kvaliteta učenja odvisna tudi od pomena posredovane informacije. Mladostniki imajo manj težav pri učenju nesmiselnih neologizmov ali bizarnih besednih zvez. Odrasli imajo pri prepoznavanju in obnavljanju takšnega novega znanja več težav in naredijo tudi več napak. Če je informacija pomensko relevantna, smiselna in realno možna, potem se število napak pri odraslih očitno zmanjša. Po Myersu je vzrok za takšen »popravek « v kristalizirani dimenziji inteligentnosti, saj odrasli informacije umeščajo v bogato paleto življenjskih izkušenj, v katerih imajo nesmiselni neologizmi manjšo veljavo. To je proces, ki novo znanje opremi z dodatnimi čustvenimi predznaki. Novo znanje se integrira v obstoječo paleto znanja, ki je bilo pridobljeno skozi izkušnje in je trdnejše, uporaba tega novega znanja pa bolj suverena. Negativne posledice kristaliziranega znanja so seveda daljši produkcijski čas, ubeseditev in rigidnost takšnega znanja.

Raziskovalci, ki se ukvarjajo s kapacitetami učenja in spomina, se prav tako zavedajo pomembnosti relativno velike notranje variabilnosti odraslih (variabilnost znotraj opazovane skupine). To pomeni, da so razlike pri spominskih sposobnostih med dvajsetletniki precejšnje, vendar so pri šestdesetletnikih bistveno večje. Tako lahko ima neki šestdesetletnik zelo slabe rezultate pri osvajanju novega znanja, drugi šestdesetletnik pa je na tem področju nadpovprečen tudi v primerjavi z dvajsetletniki (Myers, 2007: 183).

Videli smo, da kognitivno staranje vpliva na učinkovitost učenja v odrasli dobi. Ali to hkrati pomeni, da upada tudi inteligentnost? Prvotne medsekcijske raziskave so to sicer nakazovale, a so se kaj hitro pojavile interpretativne težave. Ko so se primerjale učne sposobnosti denimo sedemdesetletnikov in tridesetletnikov, se niso primerjali samo konkretni subjekti s svojimi psihološkimi sposobnostmi, ampak sta se primerjala tudi dva družbena in izobraževalna sistema. V splošnem se je primerjal slabši izobraževalni sistem sedemdesetletnika s posodobljenim in nadgrajenim družbenim kontekstom tridesetletnika, ki je imel tudi boljše socialne in kulturne pogoje za razvoj svojih izobrazbenih potencialov. Zato so medsekcijske raziskave kmalu zamenjale longitudinalne študije, ki so to težavo delno odpravile, potrdile pa so tudi dve dimenziji inteligentnosti, ki se v različnih življenjskih ciklih različno razvijajo.

Kar je posebno pomembno za razumevanje strategij učenja odraslih, je torej raziskovalno potrjeno dejstvo, da fluidna in kristalizirana inteligentnost približno enakomerno naraščata do adolescence, ob koncu mladostništva naraščanje fluidne inteligence upade, kristalizirana inteligentnost pa narašča in se razrašča vse do poznega življenjskega obdobja. 


\section{UČNI STILI ODRASLIH - KRATKI PREGLED}

Raven višje od aktivnosti možganov odrasle osebe je psihološka raven znanstvenega opazovanja. Za izobraževalce in raziskovalce izobraževanja odraslih so v tem segmentu izjemno zanimive različne učne strategije odraslih. Uspešnost učenja odraslih namreč ni odvisna samo od tega, kako dobro so se odrasli sposobni učiti, ampak tudi od tega, na kakšen način se učijo (Sperberg, 1997: 18). Ko govorimo o učnih stilih oziroma zaznavnih modalitetah, je treba poudariti, da pri tem ne gre za kognitivne sposobnosti, ampak za oblike uporabe teh kognitivnih sposobnosti. Odrasli s popolnoma enakimi kognitivnimi sposobnostmi so lahko v nekem kontekstu uspešnejši od drugih prav zaradi ustreznejših učnih stilov, velikokrat pa raziskovalci in izobraževalci takšne posameznike napačno vrednotijo kot tiste, ki imajo boljše kognitivne sposobnosti.

Tipologij učnih stilov je več. Na kratko omenimo tri, ki so za razumevanje učenja odraslih iz ranljivih skupin v okvirih kognitivnih teorij učenja najbolj uporabne. Prvi model učnih stilov temelji na Gardnerjevem modelu multiplih inteligenc, zelo vplivnem konceptu v izobraževanju odraslih. Gardner je v svojem modelu izhajal iz predpostavke, da lahko govorimo o različnih inteligencah, ki so med sabo ločene in starostno variirajo: včasih je bolj izražena ena oblika inteligence, drugič druga. Po Gardnerjevem mnenju se v šolskem sistemu pozornost namenja predvsem matematični (pod)inteligenci, zato je vloga izobraževalcev odraslih, da vzpostavljajo pogoje za razvoj drugih šestih inteligenc: verbalno-lingvistične (sposobnost jezikovnega sporazumevanja), logično-matematične (deduktivno mišljenje, sposobnosti za delo s številkami in dobre računske strategije), vizualno-prostorske (dobra orientacija, konstrukcija podob in ocenjevanje prostora), telesno-kinetične (psiho-motorične kompetence), glasbeno-ritmične (prepoznavanje glasbenih vzorcev, ritmov in harmo- nij), medosebne (komunikacijske veščine) in intrapersonalne inteligence (duhovne in samorefleksivne sposobnosti) (Gardner, 1993). Vsaka od teh (pod)inteligenc zahteva nekoliko drugačno učno strategijo: »Sedem inteligenc bi dovoljevalo sedem načinov poučevanja namesto enega samega. In vse močne omejitve, ki obstajajo v umu, je mogoče izkoristiti pri uvajanju nekega pojma (ali celo sistema mišljenja) na tak način, da se ga bodo otroci s kar največjo verjetnostjo naučili in da obstaja kar najmanjša verjetnost, da ga bodo izkrivili.« (Gardner, 1993: 22.) Ob tem opomnimo, da je Gardnerjev model multiplih inteligenc raziskovalno sicer šibko podprt. Večina sodobnih raziskav kaže, da človeška kognicija ne deluje s pomočjo sedmih različnih podsistemov inteligenc. Je pa takšen shematski prikaz zelo pragmatičen in kot prispodoba uporaben za izobraževalce odraslih v praksi.

Drug pomemben model učnih stilov je zasnoval David Kolb. Kolb umešča učne stile med štiri razsežnosti, ki so: aktivno eksperimentiranje, reflektivno opazovanje, konkretno izkustvo in abstraktna konceptualizacija. Vsaka razsežnost pomen eno točko $\mathrm{v}$ štiridimenzionalnem polju, vmesni prostor med razsežnostmi pa izpopolnjuje eden od štirih možnih profilov učenja. Tako je na primer med aktivnim eksperimentiranjem in abstraktno konceptualizacijo »aktivist «, med reflektivnim opazovanjem in konkretnim izkustvom pa »teoretik «. Vsak od štirih učnih stilov se pri posamezniku kaže na svoj način: aktivist se raje zanaša na intuicijo kot na logiko, uporablja analize drugih ljudi, ima rad prakso in eksperimentalni pristop. Refleksivnež je sposoben videti težave iz alternativne perspektive, je dojemljiv za spremembe, je bolj vizualen tip, za reševanje problemov pa uporablja miselne eksperimente. Teoretik zagovarja logičen pristop, ideje in koncepte postavlja pred ljudi, zahteva jasne, preverljive razlage in se ne zanaša preveč na praktične izkušnje iz vsakodnevnega življenja. Pragmatik rešuje težave zelo praktično, bliže 
so mu tehnične naloge, manj pa ga zanimajo zgodbe ljudi in mehke, interpretativne teorije. Tretji model učnih stilov kot glavni kriterij klasifikacije jemlje dotok dražljajev (vizualni, slušni, kinestetični, haptični itd.). Ta model izhaja iz dveh prej omenjenih shem, vendar je poudarek na dražljajih, na načinih, kako prejemamo novo znanje. Poenostavljeno to pomeni, da vizualni posamezniki radi vidijo nove informacije $\mathrm{v}$ obliki grafov, prikazov, vizualizacij in videomateriala. Posamezniki, ki dajejo prednost slušnemu zaznavnemu kanalu, nove vsebine radi slišijo v obliki predavanja, kaset, zvočnic, glasbe, zanimivi so jim tudi detajli. Posamezniki, ki jim je blizu kinestetični pristop, se med učenjem radi gibljejo itd. (Marrapodi, 2011). Vse te pridobljene nove informacije so »surovi podatki«. Temu, po katerem čutnem dovodu najraje pridobivamo znanje, pravimo dominantna zaznavna modaliteta (Wislock, 1993). Vsi preostali zaznavni kanali so dominantni modaliteti podrejeni, čeprav se včasih pojavljata dve enako učinkoviti zaznavni modaliteti (govorimo o mešani zaznavni modaliteti) ali pa so razlike med prevladujočim in drugim zaznavnim kanalom glede na učinkovitost $\mathrm{v}$ učenju minimalne (primarna in sekundarna zaznavna modaliteta). Dominantna zaznavna modaliteta se vzpostavi že v otroštvu in se po mnenju Keefa (v Wislock, 1993: 6) radikalno v življenju več ne spreminja. Gre torej za razmeroma stabilno osebnostno lastnost. Preferenčna zaznavna modaliteta za kognicijo pomeni glavni dovod novih informacij in učenje je lahko okrnjeno, če je dotok informacij površen ali nove informacije niso posredovane na ustrezen način.

$\mathrm{Na}$ dominanti modaliteti posameznika utemeljeno poučevanje je za Barbe in Swassing (1988: 14) ena $» . .$. najpomembnejših strategij poučevanja, saj pomeni okvir duševnosti, ki usmerja povezovanje med življenjskim razvojem in učenjem«. Po mnenju Wislocka bi moralo biti to zavedanje vedno $\mathrm{v}$ ospredju izobraževalcev odraslih. Če se pozabi na načelo dominantne modalitete, se lahko kaj hitro zgodi, da izobraževalec odraslih $\mathrm{v}$ ospredje nenamerno postavi svojo dominantno zaznavno modaliteto. Ključna lastnost dobrega izobraževalca odraslih je tako tudi kritična vzpostavitev distance do lastne dominantne zaznavne modalitete.

Čeprav je jedro dominantne zaznavne modalitete vzpostavljeno že v otroštvu, je Harter (Wislock, 1993: 7) opravil raziskavo, v kateri je opazoval spremembe $v$ preferencah zaznavnih modalitet skozi različna življenjska obdobja. Ugotovil je, da je od rojstva do šestega leta starosti najmočnejši zaznavni dovod vid, sledi kinestetično učenje, na zadnjem mestu pa je slušno učenje. Od končnih razredov osnovne šole do odraslega obdobja vizualno učenje ostaja preferenčno pri večini udeležencev raziskave, praviloma se na drugo mesto uvršča slušno učenje, najmanj pomembno pa postane kinestetično učenje. V dopolnilni študiji, ki sta jo izvedla James in Galbraith (v Wislock, 1993: 7), se je izkazalo, da je vid dominantna modaliteta tudi med tistimi, ki so stari od 20 do 50 let. Zanimivo pa je, da se je kot druga najpomembnejša zaznavna modaliteta pokazalo haptično učenje, torej s pomočjo dotika $\mathrm{z}$ rokami. Interaktivno učenje je bilo na tretjem mestu, slušno pa na četrtem. Za starejše od 50 let vizualno učenje pričakovano ostaja hegemonsko, na drugem mestu je interaktivno učenje (razprava o idejah v skupini), sledi slušno učenje, prioritetno lestvico 50-letnikov pa zaključuje haptično učenje.

Ko izobraževalci odraslih ustrezno tipizirajo dominantne zaznavne modalitete svoje ciljne skupine, lahko uskladijo obliko posredovanja novega znanja s potrebami te ciljne skupine. Po mnenju Wislocka je najbolj varno izbrati multisenzorični pristop. Pri tem snovalci programa uporabljajo pestro paleto medijev in formatov $\mathrm{z}$ namenom, da hkrati stimulirajo različne zaznavne kanale, s čimer skušajo doseči večjo učinkovitost učenja. Ta pristop je dober za poučevanje v primerih, ko imamo zelo različne ciljne skupine, ali za posamezni- 
ke, za katere ne vemo, kakšni so njihovi učni stili (Wislock, 1993: 10). Tako lahko vsak zase najde primerne vsebine po poti (vizualno, slušno, z dotikom itd.), ki je zanj najustreznejša. A ima izbor multisenzoričnega pristopa tudi negativne učinke. Eden takšnih je že omenjena »mentalna navlaka«, o kateri sta govorila Haser in Zack (Mast, Zimmerman, Rowe, 2009: 697).

Zastavlja se tudi vprašanje, kakšen vpliv ima pravzaprav izbor ustreznega učnega stila na celostno učinkovitost učenja odraslih. Erhman je leta 1990 izvedel raziskavo, v kateri je spremljal, kako se učijo študenti. Zaznal je osem različnih strategij učenja (od glasnega branja do skupinskih in kampanjskih učnih seans) in ugotovil, da med štirimi glavnimi dejavniki (spol, preživljanje prostega časa, starost in učni stili) prav učni stili najbolj vplivajo na učinkovitost učenja (Marrapodi, 2011).

Sklenemo lahko, da je razumevanje učnih stilov oziroma dominantnih zaznavnih modalitet nujno. Gre za razmeroma star koncept, ki ga je v strokovni diskurz prvič vpeljal Allport že leta 1937, a šele v zadnjih dveh desetletjih se učni stili proučujejo raziskovalno. Pomemben prispevek temu področju sta leta 1985 dodala James in Galbraith, ki sta proučevala, kako se dominantne zaznavne modalitete spreminjajo skozi različna življenjska obdobja, in v obravnavo prvič vključila tudi odrasle.

\section{KONKRETNO PODROČJE IZOBRAŽEVANJA: PISMENOST IN RANLJIVE SKUPINE}

Poglejmo za konec, kaj lahko sodobne kognitivne študije učenja odraslih povedo o zelo konkretnem področju izobraževanja - pismenosti odraslih iz ranljivih družbenih skupin. Ardila s sodelavci (2010: 689) izhaja s predpostavke, da posamezniki iz ranljivih družbenih skupin dosegajo nižjo raven splošne pismenosti in izobrazbe, izhajajo iz nižjega družbenoekonomskega razreda, imajo več zdravstvenih težav, so manj izpostavljeni medijem komunikacije ter imajo omejene možnosti in izkušnje preverjanja informacij, ki so posredovane prek množičnih medijev. Po njegovem mnenju vsi ti socio-kulturni dejavniki, s poudarkom na nizki ravni pismenosti, vplivajo tudi na specifičen pogled na svet.

Kosmidis in sodelavci (v Ardila in drugi, 2010) so izvedli raziskavo s pripadniki ranljivih družbenih skupin ter jih primerjali z bolj izobraženimi in pismenimi odraslimi iz višjih družbenoekonomskih razredov. Opazovali so, kakšen je vpliv izobrazbe in pismenosti na učenje in pridobivanje novega znanja ob različnih socialnih pogojih, v katerih živijo udeleženci. Kosmidis je tako ugotovil, da izobrazba vpliva na leksikalno odločanje, pismenost pa na zmogljivost fonološke zanke. Fonološka zanka oziroma zaznava se nanaša na različne aktivnosti, ki povečujejo občutljivost posameznika

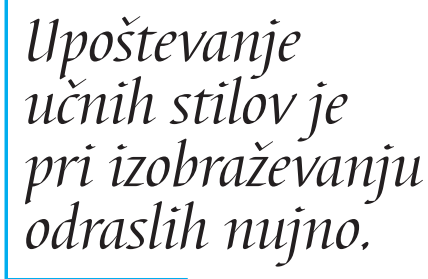

za glasove in uporabo teh glasov v besedah (Pečjak, 2010: 28). Sodobnejše raziskave s področja nevrofiziologije pismenosti nedvomno utrjujejo domnevo, da stopnja izobrazbe in raven pismenosti ključno vplivata na nevronske povezave, ki so vpete $\mathrm{v}$ reševanje problemov oziroma nalog (ang. problem-solving neuron network). Številne raziskave dokazujejo razlike $\mathrm{v}$ sposobnosti branja in razumevanja tako imenovanih psevdobesed in stvarnih, realnih besed. Izkazalo se je, da se rezultati med slabše izobraženimi in manj pismenimi ter bolj izobraženimi bistveno bolj razlikujejo, ko gre za zaznavo psevdobesed, manj pa, ko gre za zaznavo tistih besed, ki se uporabljajo v vsakodnevnem življenju (Ostrosky-Solis in drugi v Ardila in drugi, 2010).

Zanimiva je tudi raziskava Carreirasa iz leta 2009, ki se je osredotočil na tiste, ki so se naučili brati ali dvignili raven pismenosti $\mathrm{v}$ odrasli dobi. S pomočjo funkcionalne magnetne resonance (fMRI) je primerjal možganske 
posnetke nepismenih odraslih s tistimi, ki so aktivno dvigovali raven pismenost $\mathrm{v}$ odrasli dobi. Ugotovil je, da je pri nepismenih del možganov, odgovoren za interhemisferično komunikacijo (povezavo med levo in desno možgansko hemisfero), imenovan »corpus callosum«, šibkejši. Pri skupini, ki si je aktivno prizadevala za dvig splošne pismenosti, pa je bila ta stična točka obeh hemisfer močnejša in širša, z dodatnimi izobraževalnimi aktivnostmi se je še utrjevala. Te razlike Carreiras pripisuje dejavniku izobraževanja in pismenosti, zaključuje pa z ugotovitvijo, da branje krepi interhemisferično povezljivost, s tem pa optimizira celostno zaznavo stvarnosti. Ardila v splošnem zaključuje, da sodobne raziskave s pomočjo fMRI podpirajo tezo, da višja raven pismenosti pri odraslih ne lajša samo vsakodnevne aktivnosti in izboljšuje strategijo mišljenja, ampak višja raven pismenosti vpliva tudi na funkcionalno arhitekturo odraslih človeških možganov (Ardila in drugi, 2010: 694). Omenimo še raziskavo Castro-Caldasa, ki je s pomočjo magnetnega encefalografa (MEG) preverjal, ali obstajajo kakršnekoli razlike $\mathrm{v}$ nevrofiziološkem delovanju pri odraslih, ki se naučijo brati in pisati v odrasli dobi, in tistimi, ki so branje in pisanje osvojili v otroštvu. Raziskavo je opravil tako, da je med branjem besedila spremljal možgansko aktivnost udeležencev eksperimenta. Ugotovil je, da je bilo branje (ang. reading performance) enako, pojavile pa so se razlike v distribuciji možganske aktivnosti med branjem: pri tistih, ki so se branja in pisanja učili v odrasli dobi, je bilo več možganske aktivnosti zaznane $\mathrm{v}$ desnem senčnem in temenskem režnju nove možganske skorje, pri kontrolni skupini (pismeni od otroštva) pa je bila intenzivnejša možganska aktivnost zaznana v levem delu čelnega režnja nove možganske skorje. Učenje branja v različnih življenjskih obdobjih je torej povezano z različnimi deli nove možganske skorje. Kot podporno študijo je Castro-Caldas primerjal še skupino sedmih žensk, ki so se naučile brati in pisati po 50. letu, s skupino desetih žensk, ki so končale desetletno šolanje ter pisale in brale od mladosti. Zdaj je Castro-Caldas s pomočjo MEG opazoval možgansko aktivnost med testom prepoznavanja jezika (ang. language recognition test). Rezultati testa so bili podobni. V primerjavi s kontrolno skupino naj bi bila skupina žensk, ki so se naučile brati in pisati po 50. letu, manj podvržena evolucijsko pogojeni funkcionalni asimetričnosti možganov, kar pomeni, da sta bili $\mathrm{v}$ proces branja in pisanja vpeti obe možganski hemisferi. Pri kontrolni skupini to ni bilo ugotovljeno, saj je bila tam asimetrija zelo očitna. Castro-Caldas zato sklene, da »... slabše izobraženi posamezniki očitno uporabljajo možgane za procesiranje informacij na drugačen način, kot to počno posamezniki $\mathrm{z}$ višjo izobrazbo ali ki so bili izšolani v predvidenem mladostnem obdobju« (Ardila, 2010: 699).

Splošna pismenost vpliva na vizualno zaznavo, logično sklepanje, uporabo strategij učenja in (post)formalno operativno fazo mišljenja. To pa ne pomeni, da slabi rezultati na različnih kognitivnih testih nujno izhajajo iz atipične možganske aktivnosti. Po mnenju Ardile (2010: 707) je zato optiko opazovanja (in reševanja) problematike treba obrniti na glavo. Ne gre (več) za to, da bi bolj izobraženi posamezniki imeli dodatne kognitivne potenciale, ampak za to, da manj izobraženi posamezniki iz ranljivih skupin zaradi odsotnosti ugodnih družbenih pogojev ne morejo optimalno razviti svojih naravno danih kognitivnih potencialov.

\section{KOGNITIVNA TEORIJA UČENJA - NUINA, A NE ZADOSTNA RAZLAGA UČENIA ODRASLIH}

Kot smo že poudarili, lahko kognitivna teorija učenja pojasni temeljne univerzalne kognitivne procese, s katerimi dojemamo, razumemo in skladiščimo novopridobljeno znanje. Pri tem 
je kognitivna teorija razmeroma uspešna, saj gre za evolucijsko pogojene in genetsko determinirane biološke avtomatizme, kjer je vpliv socialnega in kulturnega konteksta razmeroma šibak. Prva takšna uveljavljena ugotovitev je, da se sodobne kognitivne teorije učenja osredotočajo na skupne, univerzalne principe delovanja človeških možganov in interpretiranja sveta okoli nas. Razlike med odraslimi posamezniki so za kognitivno psihologijo drugotnega pomena, zato nas ne bi smelo presenetiti nesorazmerje med raziskavami kognitivne psihologije, ki se ukvarja z razvojnimi tematikami, in raziskavami, ki se dotikajo kognicije odrasle osebe; prvih je seveda velika večina.

Druga pomembna inovacija, ki jo vpeljujejo sodobne kognitivne teorije učenja, je upoštevanje t. i. postformalne faze mišljenja, ki je značilna za obdobje odraslosti. Kot smo videli, se po Piagetu kognitivnemu odraščanju v odrasli dobi ni namenjala posebna pozornost. Neopiagetovski pristop s svojim vztrajanjem pri »4+« fazah kognitivnega razvoja tako odpira konceptualni prostor za sistematično raziskovanje odrasle kognicije, ki je v preteklosti umanjkal. V odraslem obdobju postane izjemno pomembna kristalizirana inteligentnost (Myers, 2007).

Razumevanje dvotirnega dojemanja in sprejemanja novega znanja $\mathrm{v}$ odraslem obdobju dodatno osvetljuje odraslo inteligentnost in proces učenja v poznem obdobju življenja. Če bi morali izbrati ključne lastnosti kristalizirane inteligentnosti, bi omenili, da je intenzivno kontekstualna, kulturno in socialno pogojena ter primarno pragmatično naravnana. Nevrofiziološke raziskave možganske aktivnosti, predvsem primerjava gostote sinaptičnih povezav $\mathrm{v}$ različnih življenjskih obdobjih, pa potrjujejo domnevo, da je vizualna zaznava hegemonski čutni dovod tako za otroka in mladostnika kot za odraslo osebo. Med preostalimi zaznavnimi modalitetami je pogostejše še kinestetično učenje. Zaradi notranje variabilnosti odraslih je razumevanje različnih učnih stilov in njihovo prepoznavanje v praksi lahko zelo koristno.

Mnoge raziskovalce ob tako jasno nanizanih sklepih zamika, da bi kognitivnim teorijam učenja pripisali večjo pojasnjevalno moč, kot jo dejansko imajo. To se ne bi zgodilo prvič. Podobna težnja se je v zgodovini družboslovnega raziskovanja že enkrat uresničila v nerodni sociobiologiji E. O. Wilsona, ko je vzročno-posledične razlage celotnega socialnega vedenja posameznika iskal $\mathrm{v}$ genetiki človeka. Danes je takšna radikalna redukcija le še akademski opozorilni znak za prepovedano smer. Kako se novo znanje uporablja v vsakdanjem življenju, kakšna je učinkovitost tega znanja, kako se oblikuje svetovni nazor in kako kopiči modrost, vse to ostajajo odprta vprašanja, na katera kognitivne teorije učenja niso in ne morejo odgovoriti. In na srečo se tega zavedajo tudi njihovi avtorji. Čeprav v sodobnih kognitivnih teorijah govorimo o rigoroznih znanstvenih kriterijih in nadzorovanih eksperimentalnih pogojih, lahko kognitivno raziskovanje učenja pojasni samo manjši del kompleksnega fenomena učenja odraslih. Dejavniki, ki vplivajo na učinkovitost učenja odraslih v socialnem kontekstu, so enostavno preveč obteženi z zunanjimi kulturnimi vplivi. Egan (2009: 79-80) jedrnato povzema to misel: »Poanta je, da je naša kultura tako močno utelešena in 'vumljena (ang. inminded), da je težko ugotoviti, kaj je naša najgloblja narava oziroma ali je naša nepredelana narava dosegljiva pod naloženo kulturo. Ideja, da narave nimamo, je pretiravanje. Imamo jo, toda vse teže in teže jo je dognati pod plastmi nakopičenih in vumljenih kognitivnih orodij.« Illeris (2009: 21) to spoznanje prenese na učenje, ko pravi, da je učenje kompleksen biološki, psihološki, sociološki in kulturološki proces, ki ga je treba $\mathrm{v}$ znanstvenih raziskavam temu primerno obravnavati. $\mathrm{V}$ tem smislu pomenijo konstrukcionistične, sistemsko funkcionalne, 
sociološke, antropološke in predvsem konektivistične teorije smiselno nadgradnjo kognitivnih izhodišč za razumevanje učenja odraslih iz ranljivih skupin.

Kar lahko kognitivne znanosti za zdaj dokončno potrdijo, je to, da raziskovanje učenja presega individualno, nevrološko raven. Torej priznavajo svojo omejenost. S tem pa smo korak naprej od dolgotrajnih ideoloških bojev med družboslovjem in naravoslovjem ter korak bliže interdisciplinarni razlagi učenja, ki jo bomo - upajmo - dobili v prihodnosti.

\section{LITERATURA}

Anderson, J. R. (1995). Learning and Memory. An Integrated Approach. New York: John Wiley \& Sons inc.

Ardelt, M. in Jacobs, S. (2009). »Wisdom, Integrity, and Live Satisfaction in Very Old Age «. V: Smith, C. M., Handbook of Research of Adult Learning and Development. New York: Routledge.

Ardila, A. in drugi (2010): Literacy: The Neuropsychology of Cognition Without Reading. Oxford: Oxford University Press.

Bakračevič Vukman, K. (2000). Razvoj mišljenja v odrasli dobi. Kognitivni, sociokognitivni in metakognitivni aspekti. Maribor: Pedagoška fakulteta.

Bernardo, A. B. I. (1998). Literacy and the Mind. The Contexts and Cognitive Consequences of Literacy Practice. Hamburg: UNESCO Institute for Education.

Blanchard-Fields, F. in Kalinauskas, A. S. (2009). »Challenges for the Current Status of Adult Developmental Theories: A New Century of Progress «. V: Smith, C. M., Handbook of Research of Adult Learning and Development. New York: Routledge.

Bregar, L., Zagmajster, M., Radovan, M. (2010). Osnove e-izobraževanja. Priročnik. Ljubljana: Andragoški center Slovenije.

Driscoll, M. P (2000). Psychology of learning for instruction. Massachusetts: Allyn \& Bac.

Egan, K. (2009): Zgodovina pedagoške zmote. Ljubljana: Založba Krtina.

Gardner, H. (1995). Razsežnosti Uma. Ljubljana: Tangram.

Illeris, K. (2007). How We Learn. New York: Routledge.

Illeris, K. (2009). Contemporary Theories of Learning. New York: Routledge.
Janko, A. (1997). Izobraževanje in strategije pismenosti. Magistrsko delo. Ljubljana: Filozofska fakulteta.

Malone, J. C. (1991). Theories of Learning. A Historical Approach. Belmond: Wadsworth Publishing Company.

Marraprodi J. (2011). »Learning Styles of low literacy Learners «. A Review of the Literature. (dostopno 16. 2. 2011 na www.applestar. org/.../Learning\%20Styles\%20of\%20Low\%20 Literacy\%20Learners.doc)

Mast, B. T., Zimmerman, J., Rowe, S. V. (2009). »What Do We Know About the Aging Brain?: Implication for Learning in Late Life«. V: Smith, C. M., Handbook of Research of Adult Learning and Development. New York: Routledge.

Myers, D.G. (2007). Psychology. New York: Worth Publishers.

Pečjak, S. (2010). Psihološki vidiki bralne pismenosti, od teorije k praksi. Ljubljana: Znanstvenoraziskovalni inštitut Filozofske fakultete.

Reif, F. (2008). Applying cognitive science to education: thinking and learning in scientific and other compley domans. Cambridge: The MIT Press.

Sinnott, J. D. (2009). »Cognitive Development as the Dance of Adaptive Transformation: Neo-Piagetian Perpectives on Adult Cognitive Development «. V: Smith, C. M., Handbook of Research of Adult Learning and Development. New York: Routledge.

Sternberg, R. J. (1999). Cognitive Psychology. Orlando: Rinehart and Winston.

Sternberg, R. J. (1997). Thinking Styles. Cambridge: Cambridge University Press.

Thomson, D. (2009). »A Brief History of Research and Theory on Adult Learning and Cognition«. V: Smith, C. M., Handbook of Research of Adult Learning and Development. New York: Routledge.

Wislock, R. F. (1993). »What Are Perceptual Modalities and How Do They Contribute to Learning?«. V: Flannery, D. D., Applying Cognitive Learning Theory to Adult Learning. New Directions for Adult and Continuing Education, št. 59., Tennessee. 